\author{
AgNIESZKA ŚWIĘTEK \\ Uniwersytet Pedagogiczny w Krakowie, Polska - Pedagogical University of Cracow, Poland \\ TOMASZ RACHWAE \\ Uniwersytet Pedagogiczny w Krakowie, Polska - Pedagogical University of Cracow, Poland \\ StAWOMIR KUREK \\ Uniwersytet Pedagogiczny w Krakowie, Polska - Pedagogical University of Cracow, Poland \\ WIOLETTA KILAR \\ Uniwersytet Pedagogiczny w Krakowie, Polska - Pedagogical University of Cracow, Poland \\ WIKTOR OSUCH \\ Uniwersytet Pedagogiczny w Krakowie, Polska - Pedagogical University of Cracow, Poland
}

\title{
Sytuacja młodzieży NEET w Polsce i propozycje podniesienia jej kompetencji przedsiębiorczych w świetle rezultatów projektu RLG
}

\author{
Situation of NEETs in Poland and Proposals for Developing their Entrepreneurial \\ Competences in Light of the Results of the RLG Project
}

\begin{abstract}
Streszczenie: Przedmiotem artykułu jest sytuacja młodzieży NEET (niepracującej i nieuczestniczącej $\mathrm{w}$ formalnej edukacji, ang. not in employment, education or training) w Polsce na tle Europy. W artykule autorzy przedstawiają zróżnicowanie udziału młodzieży NEET w krajach europejskich, zwracając szczególną uwagę na młodzież bezrobotną oraz przedwcześnie porzucającą edukację. Diagnozują sytuację młodzieży NEET w Polsce za pomocą ekspercko-statystycznego modelu monitorowania sytuacji na rynku pracy oraz wskaźnika syntetycznego sytuacji młodzieży na rynku pracy i na tej podstawie wskazują możliwości poprawy sytuacji młodzieży NEET. Szczególne możliwości w tym zakresie przypisują rozwojowi kompetencji przedsiębiorczych tej młodzieży, wskazując jako celowe wykorzystanie programów edukacyjnych współfinansowanych ze środków unijnych, mających na celu kształtowanie postaw przedsiębiorczych, w szczególności osiągnięć projektu RLG (ang. „Reaching the Lost Generation”). Program ten może być wykorzystany m.in. w ramach lekcji podstaw przedsiębiorczości, zarówno jako element programu kształcenia opartego na aktualnie obowiązującej podstawie programowej dla szkół ponadgimnazjalnych, jak i w przyszłości w programach opartych na nowej podstawie programowej dla szkół średnich.
\end{abstract}

Abstract: The subject of the article is the situation of NEET youth (ang. not in employment, education or
training) in Poland against Europe. In the article, the authors present the diversity of the share of youth
NEET in European countries, paying special attention to unemployed young people and early school
leavers. They diagnose the situation of NEETs in Poland using an expert-statistical model of monitoring
the situation on the labour market and an indicator of the synthetic situation of young people on the
labour market, and on this basis indicate the opportunities for improving the situation of NEETs. Special
opportunities in this respect are attributed to the development of their entrepreneurial skills, indicating
the deliberate use of educational programs co-financed from EU funds, aimed at shaping entrepreneurial
attitudes (in particular, the achievements of the RLG project). This program can be used, inter alia, as part
of entrepreneurship classes, both as part of a curriculum based on the current core curriculum for upper
secondary schools and in the future in programs based on the new core curriculum for secondary schools. 
Słowa kluczowe: bezrobocie młodych, edukacja w zakresie przedsiębiorczości, kompetencje przedsiębiorcze, NEET, RLG

Keywords: entrepreneurial competences; entrepreneurship education; NEET; RLG; youth unemployment

Otrzymano: 1 marca 2018

Received: 1 March 2018

Zaakceptowano: 25 września 2018

Accepted: 25 September 2018

\section{Sugerowana cytacja/Suggested citation:}

Świętek, A., Rachwał, T., Kurek, J., Kilar, W., Osuch, W. (2018). Sytuacja młodzieży NEET $\mathrm{w}$ Polsce i propozycje podniesienia jej kompetencji przedsiębiorczych $\mathrm{w}$ świetle rezultatów projektu RLG. Przedsiębiorczość - Edukacja [Entrepreneurship - Education], 14, 425-444. DOI: $10.24917 / 20833296.14 .29$

\section{Wstęp}

Dynamiczny rozwój nowoczesnych technologii zmieniający współczesny rynek pracy, wymagający nowych umiejętności informatycznych oraz bardzo niska obecnie stopa bezrobocia w Polsce, tworzą, jak się wydaje, bardzo dobre warunki do wejścia dzisiejszych młodych ludzi na rynek pracy. Dane gromadzone przez OECD, informacje zawarte w ostatnich raportach unijnych, a w Polsce w raportach wojewódzkich urzędów pracy, wskazują jednak, że w Europie, w tym i w Polsce, znaczny odsetek młodych osób należy do grupy NEET (ang. not in education, employment or training), której sytuacja jest przedmiotem analizy w niniejszym artykule. Określenie NEET oznacza młodych ludzi w wieku 15-24 lata (w niektórych opracowaniach autorzy rozszerzają tę grupę również na przedział wieku 15-29 lat), którzy nie pracują, tj. są bezrobotni lub bierni zawodowo, nie uczestniczą w kształceniu formalnym ani w szkoleniach podnoszących ich kwalifikacje zawodowe. Przedmiotem zainteresowania autorów w pracy badawczej była sytuacja młodzieży NEET na rynku pracy w Polsce na tle innych krajów Unii Europejskiej. Głównym celem badań była diagnoza sytuacji młodzieży NEET w Polsce oraz wskazanie możliwości i propozycji poprawy tej sytuacji. Dla osiągnięcia zakładanego celu zastosowano metody badawcze będące wybranymi fazami cyklu prakseologicznego (diagnozę, prognozowanie oraz programowanie). Pierwszą fazą badań była zatem diagnoza sytuacji członków grupy NEET na rynku pracy, wynikająca z analizy wskaźnika syntetycznego z modelu ekspercko-statystycznego monitorowania młodych na rynku pracy. Drugą fazą było przewidywanie, w ramach którego dokonano analizy czynników ryzyka NEET na podstawie kwerendy literatury i analizy raportów ekonomicznych (pochodzących z urzędów pracy, Eurostatu i GUS-u). Wykazane w pierwszych dwóch fazach jako prawdopodobne przyczyny złej sytuacji NEET na rynku edukacyjnym i zawodowym braki kompetencyjne młodzieży stały się przedmiotem zainteresowania autorów w ostatnim etapie pracy. Tak więc w trzeciej fazie dokonano analizy zakresu kompetencji przedsiębiorczych wymaganych na rynku pracy i rozwijanych w projekcie RLG, a także analizy podstawy programowej podstaw przedsiębiorczości w zakresie możliwości wdrożenia treningu kompetencji w cykl kształcenia przedmiotowego oraz pozaprzedmiotowego. 
Problem młodzieży NEET w Polsce jest przedmiotem zainteresowania autorów reprezentujących różne dyscypliny naukowe. E. Krause (2016) zauważyła, że zjawisko NEET jest jednym z ważniejszych problemów społecznych, które wymagają interwencji w większości państw Unii Europejskiej, w tym również w Polsce. Jej zdaniem, odsetek młodych osób należących do tej grupy, którą określa się m.in. jako pokolenie trzy razy nic (niepracujące, nieuczące się i nieszkolące się), przestał być bowiem marginalny, a konsekwencje tego zjawiska są coraz poważniejsze. Autorzy (Krause, 2016; Rybicka, 2014; Szcześniak, Rondón, 2011; Saczyńska-Sokół, Łojko, 2016) oprócz dyskusji nad określaniem samego pojęcia i kryteriami kwalifikacji osób do tej grupy wymieniają szereg czynników zwiększających szanse na pozostanie NEET i przyczyniających się do występowania tego zjawiska. Są to czynniki indywidualne związane m.in. z niskim poziomem wykształcenia, złą samooceną (niższe poczucie swojej wartości, niezauważanie swoich atutów), niskim poziomem kompetencji społecznych, negatywnymi postawami wobec pracy i odczuwaniem braku satysfakcji z niej, niską motywacją i niechęcią do podejmowania wysiłku w pracy, brakiem zaradności, przejawiającym się pesymistycznym nastawieniem do rzeczywistości i nieradzeniem sobie w trudnych sytuacjach życiowych. Takie podejście do życia jest przeciwieństwem szeroko rozumianej postawy przedsiębiorczej (Rachwał, 2005), traktowanej w europejskim systemie edukacji jako kompetencja kluczowa (Kompetencje..., 2007). Istnieje także wiele czynników wynikających z otoczenia zewnętrznego, które mogą wpływać na zwiększanie się tego zjawisko, takich jak niekorzystna sytuacja rodzinna, w tym obojętność wychowawcza rodziców, niska jakość instytucji szkolnych (w tym brak odpowiednich kompetencji nauczycieli do zachęcania uczniów do rozwijania postaw przedsiębiorczych, zdobywania wiedzy i umiejętności oraz zaangażowania podczas lekcji, brak indywidualnego podejścia do uczniów, nieumiejętność radzenia sobie nauczycieli ze zjawiskami patologicznymi itp.). Na występowanie zjawiska NEET mogą wpływać także czynniki makroekonomiczne, związane ze spowolnieniem gospodarczym, niemniej jednak wydaje się, że kluczowe są czynniki indywidualne, związane z podejściem danej osoby do życia. Wydaje się więc, że dzięki umiejętnemu rozbudzaniu i kształtowaniu postaw przedsiębiorczych w ramach edukacji szkolnej i pozaszkolnej możliwe jest zmniejszenie udziału osób tej grupy w ogóle populacji. Dzięki temu możliwe jest zmniejszenie szeregu negatywnych skutków związanych z występowaniem zjawiska NEET, zarówno społecznych (w tym także demograficznych związanych z opóźnieniami decyzji o zakładaniu rodzinny), jak i ekonomicznych. Choć M. Balcerowicz-Szkutnik i J. Wąsowicz (2017) zwrócili uwagę na korzystną tendencję dotyczącą spadku odsetka młodzieży niekontynuującej edukacji i wzrost odsetka osób aktywnie poszukujących zatrudnienia, należy podkreślić, że może to mieć przede wszystkim związek z poprawiającą się sytuacją gospodarczą w okresie wychodzenia z kryzysu. Nie ma więc pewności, że stan ten nie pogorszy się w podczas kolejnej recesji. Dlatego należy wypracować strategie i programy edukacyjne, które spowodują trwałą poprawę sytuacji. Jeden z programów mogących być odpowiedzią na takie zapotrzebowanie wypracowano w ramach projektu RLG.

\section{Polscy NEET na tle Europy}

Udział NEET w ogóle młodzieży w wieku 15-24 lata w poszczególnych krajach europejskich i w całej Europie wykazuje dość duże zróżnicowanie. W Europie Centralnej i Północnej sytuacja jest pod tym względem znacznie lepsza niż w Europie Południowej. 
Ryc. 1. Udział NEET wśród osób w wieku 15-24 lata w krajach UE w 2015 r. (\%)

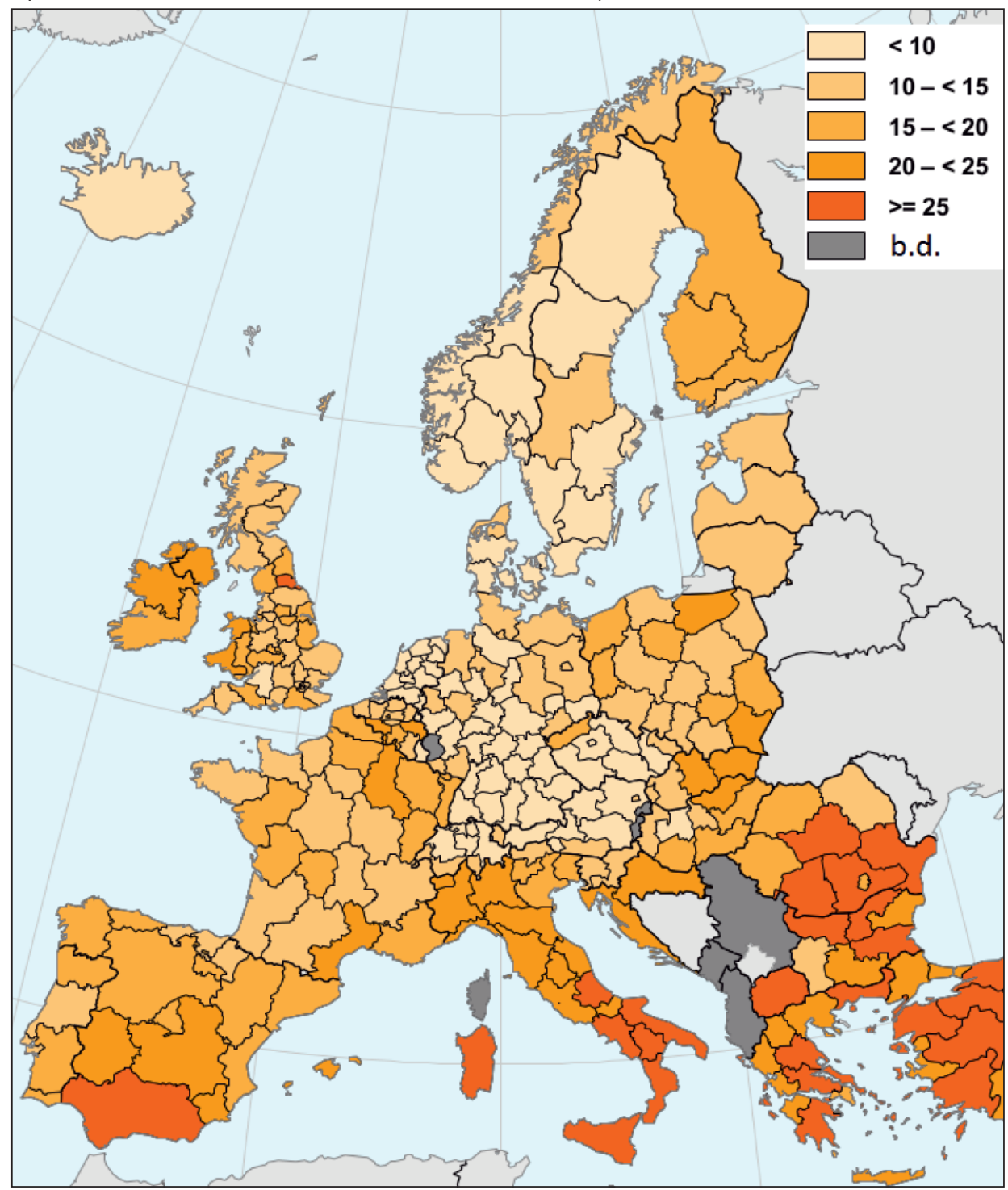

Źródło: Eurostat (EU-LFS, 2015). Online data code edat_lfse_22

W 2015 r. w Europie największy odsetek młodzieży NEET występował we Włoszech (27\%) i w Grecji (26\%), a najmniejszy - w Islandii (6,2\%), Niemczech, Luksemburgu, Szwajcarii i Holandii (ok. 8\%). Różnice między poszczególnymi krajami były więc duże i wynosiły blisko 20 punktów procentowych. Regionalne różnice (ryc. 1) są jeszcze większe. Szczególnie wysokie wartości (pow. 25\%) zanotowano wśród krajów UE, głównie w południowych regionach Włoch, południowej Hiszpanii oraz części regionów Grecji, Bułgarii i Rumunii, a także w regionach nienależącej do UE Turcji. Najlepsza sytuacja była w regionach Szwecji, Norwegii, Niemiec, Austrii i Szwajcarii. 
W Polsce w 2015 r. NEET stanowili ogółem 15,6\% (w tym 6,5\% osób bezrobotnych i 9,1\% nieaktywnych zawodowo). Najwyższy odsetek zanotowano w województwach: podkarpackim i warmińsko-mazurskim. Dane te potwierdzają wcześniejsze szczegółowe badania przeprowadzone podczas przygotowywania raportu Wsparcie młodych osób na mazowieckim rynku pracy (Mazowieckie Obserwatorium..., 2014) na poziomie NUTS2, a które wykazały silne zróżnicowanie regionalne pod względem liczby NEET w naszym kraju. Według tychże badań w 2013 r. największy udział NEET w Polsce, na poziomie 23,7\%, występował w województwie podkarpackim. Ponad 20\% NEET stanowili w województwach: lubuskim, zachodniopomorskim i warmińsko-mazurskim. Najmniejszy odsetek młodzieży NEET występował z kolei w czterech województwach tworzących rodzaj układu pasowego, przebiegającego z północnego wschodu na południowy zachód, tj. w województwach: podlaskim (13,4\%), mazowieckim (12,0\%), łódzkim $(13,8 \%)$ i śląskim (14,4\%). W województwie małopolskim wskaźnik NEET wyniósł 15,5\%. Przedstawione wyniki plasują Polskę na pozycji zbliżonej do średniej w UE.

Główne przyczyny występowania NEET wśród młodzieży europejskiej to trudna sytuacja młodzieży na rynku pracy, objawiająca się wysoką stopą bezrobocia wśród młodzieży, oraz zjawisko wczesnego porzucania szkoły.

W Europie w latach 2013-2016 najniższa stopa bezrobocia wśród młodych osób aktywnych zawodowo (w wieku 15-25 lat) występowała w Niemczech (był to jedyny kraj, w którym wynosiła ona poniżej 10\%), Austrii, Holandii i na Malcie (poniżej 15\%). W zdecydowanej większości krajów w badanym okresie mieściła się ona w granicach 15-25\%. W omawianym okresie najwyższe wartości stopa bezrobocia wśród młodzieży osiągnęła w krajach Europy Południowej: w Grecji w 2013 r. było to rekordowe 56,6\%, a w Hiszpanii 55\%. Bardzo wysoki odsetek bezrobotnych wśród młodzieży występował w tych latach

Ryc. 2. Stopa bezrobocia wśród osób młodych (15-24 lat) aktywnych zawodowo w krajach UE w latach 2013-2016

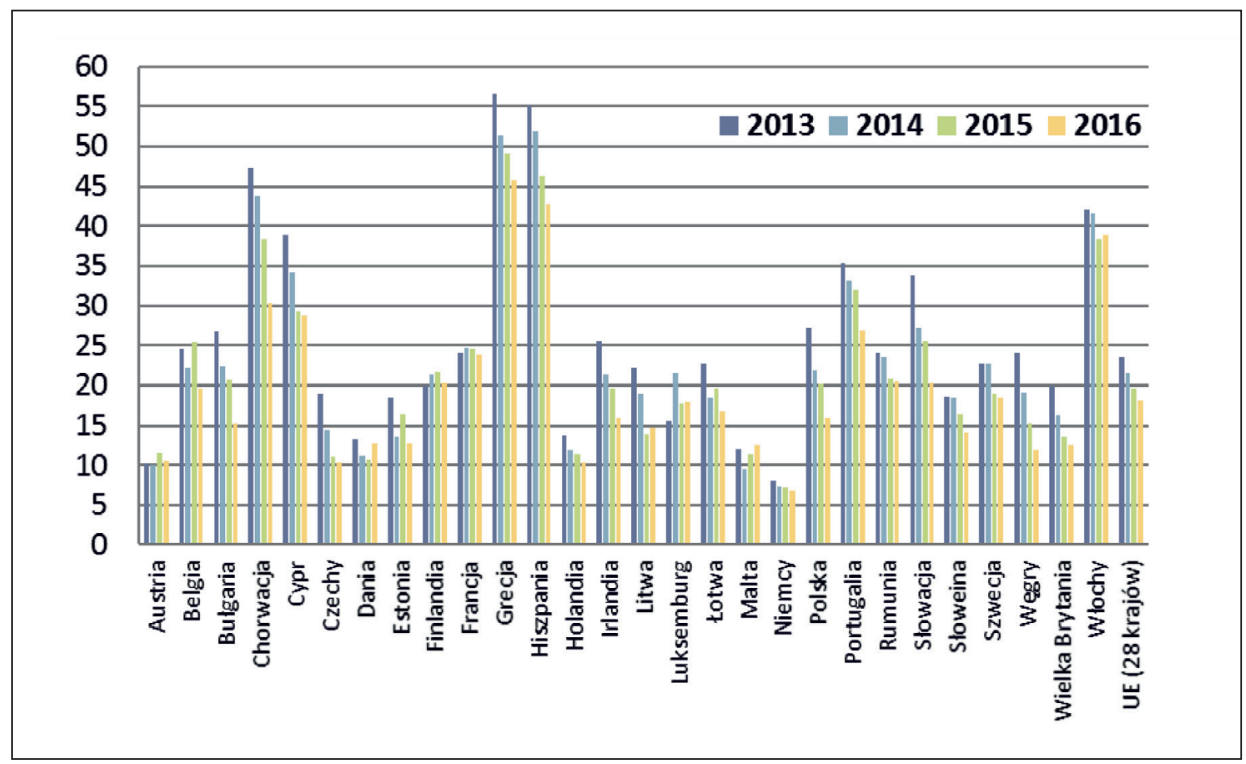

Źródło: opracowanie własne na podstawie: Eurostat (EU-LFS, 2015). Online data code edat_lfse_2 
Ryc. 3. Przedwcześnie wypadający z systemu kształcenia wg regionów NUTS 2 w Europie w 2015 r.

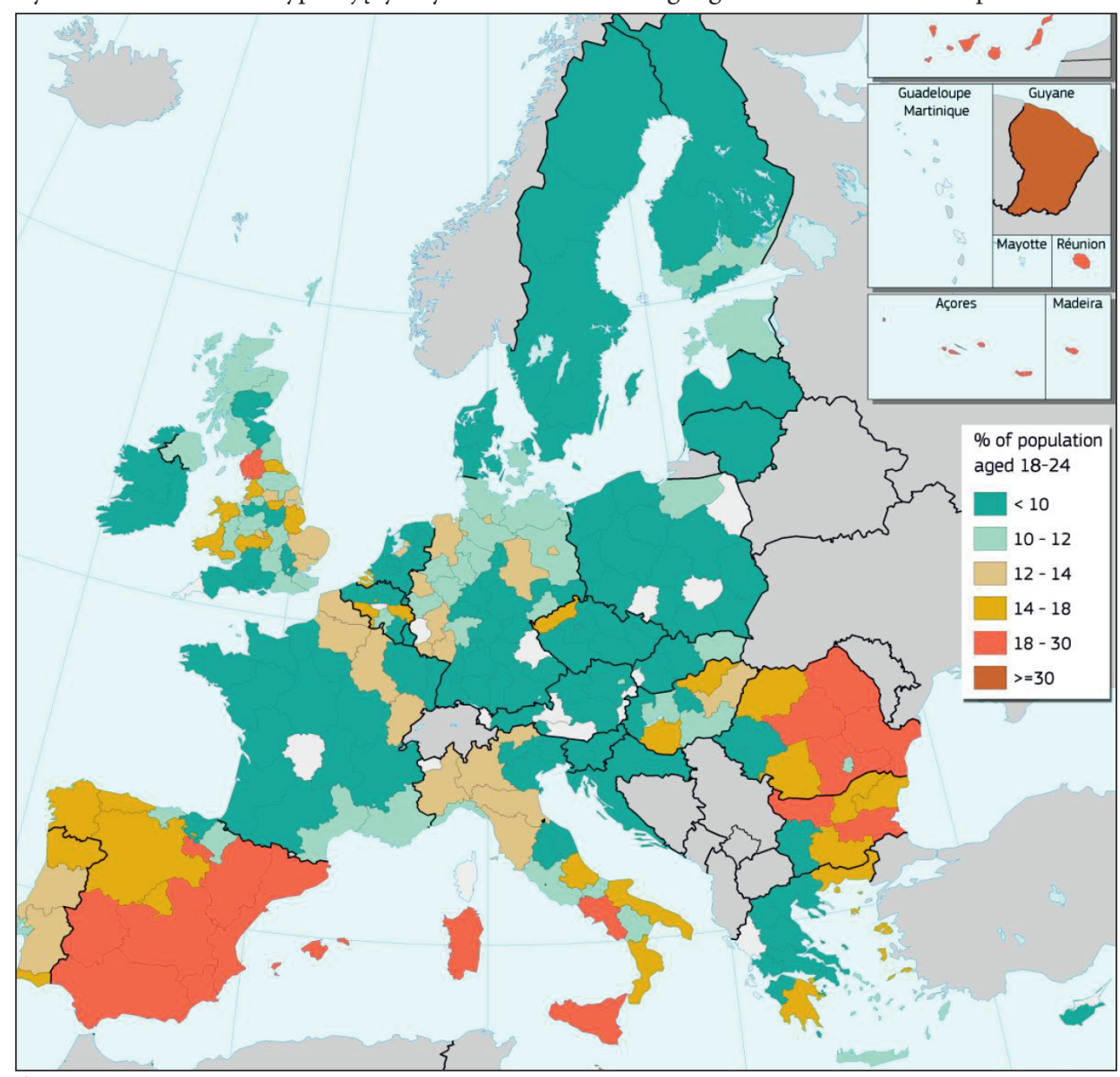

Źródło: Eurostat (EU-LFS, 2015). Online data code edat_lfse_16

również w Chorwacji (47,3\%) i we Włoszech (42,1\%). W Polsce wynosił on wtedy 27,2\%, co było wartością powyżej średniej dla Europy (ryc. 2).

W badanym okresie - 2013-2016 - zaobserwowano pozytywną tendencję w zmianach wartości stopy bezrobocia w Europie. W 24 na 28 analizowanych krajów europejskich w roku 2016 stopa bezrobocia była niższa niż w roku 2013, przy czym w większości przypadków - zdecydowanie niższa. W Polsce również poczyniono postęp w tym zakresie - stopa bezrobocia wśród młodzieży w badanym okresie spadała sukcesywnie, a w roku 2016 wyniosła 16\%, czyli spadała poniżej średniej dla UE-28.

Drugą istotną przyczyną znacznego odsetka młodzieży europejskiej należącego do grupy NEET jest zjawisko przedwczesnego porzucania szkoły (early school leaving). Polega ono na rezygnacji przez młodzież ze szkoły najczęściej na krótko przed jej ukończeniem. Zjawisko to najczęściej występuje wśród nastolatków chodzących do szkoły średniej z przyczyn osobistych (buntu wieku dojrzewania), z powodu strachu przed egzaminami zewnętrznymi, strachu przed koniecznością podjęcia decyzji dotyczącej dalszej nauki lub pracy albo braku motywacji do dalszej aktywności w tym zakresie. 
Wśród krajów europejskich w 2015 r. najwyższy odsetek młodzieży porzucającej edukację, sięgający w niektórych regionach nawet 30\%, występował w Hiszpanii, Portugalii, Włoszech, Rumunii, Bułgarii i Wielkiej Brytanii (przykładem tej grupy są tu m.in. tzw. Christmas leavers). W Polsce jest to na szczęście zjawisko marginalne, podobnie jak w całym regionie Europy Środkowej i Europy Północnej (ryc. 3).

\section{Sytuacja młodzieży na rynku pracy a odsetek NEET w Polsce}

Sytuacja polskiej młodzieży na tle młodzieży europejskiej przedstawia się dość korzystnie. Jak pokazano wyżej, w Polsce udział NEET wśród młodzieży w wieku 15-24 lata jest stosunkowo niski, niewielki odsetek młodzieży porzuca szkołę przed uzyskaniem wykształcenia na poziomie szkoły średniej, a stopa bezrobocia wśród młodych ludzi (wynosząca w 2016 r. 16\%) jest niższa od średniej europejskiej.

Korzystnie rysuje się również w ostatnich latach makroekonomiczna sytuacja Polski, ułatwiająca wejście młodych ludzi na rynek pracy. Dane dotyczące stopy bezrobocia w Polsce na koniec 2017 r. wskazują na wręcz rekordowo niskie bezrobocie (ryc. 4). W skali krajowej wyniosło ono 6,6\%, a regionalnie najniższe było w województwach: wielkopolskim (3,7\%), śląskim (5,2\%) i małopolskim (5,4\%). W największych polskich miastach było ono jeszcze niższe, np. w Warszawie wynosiło 2,0\%, w Krakowie 2,7\%, co oznacza w praktyce faktyczny brak bezrobocia, a jedynie występowanie naturalnego na rynku pracy procesu przepływu pracowników z jednych miejsc pracy do innych oraz osób, które nie chcą pracować.

Ryc. 4. Stopa bezrobocia zarejestrowanego (stan na grudzień 2017)

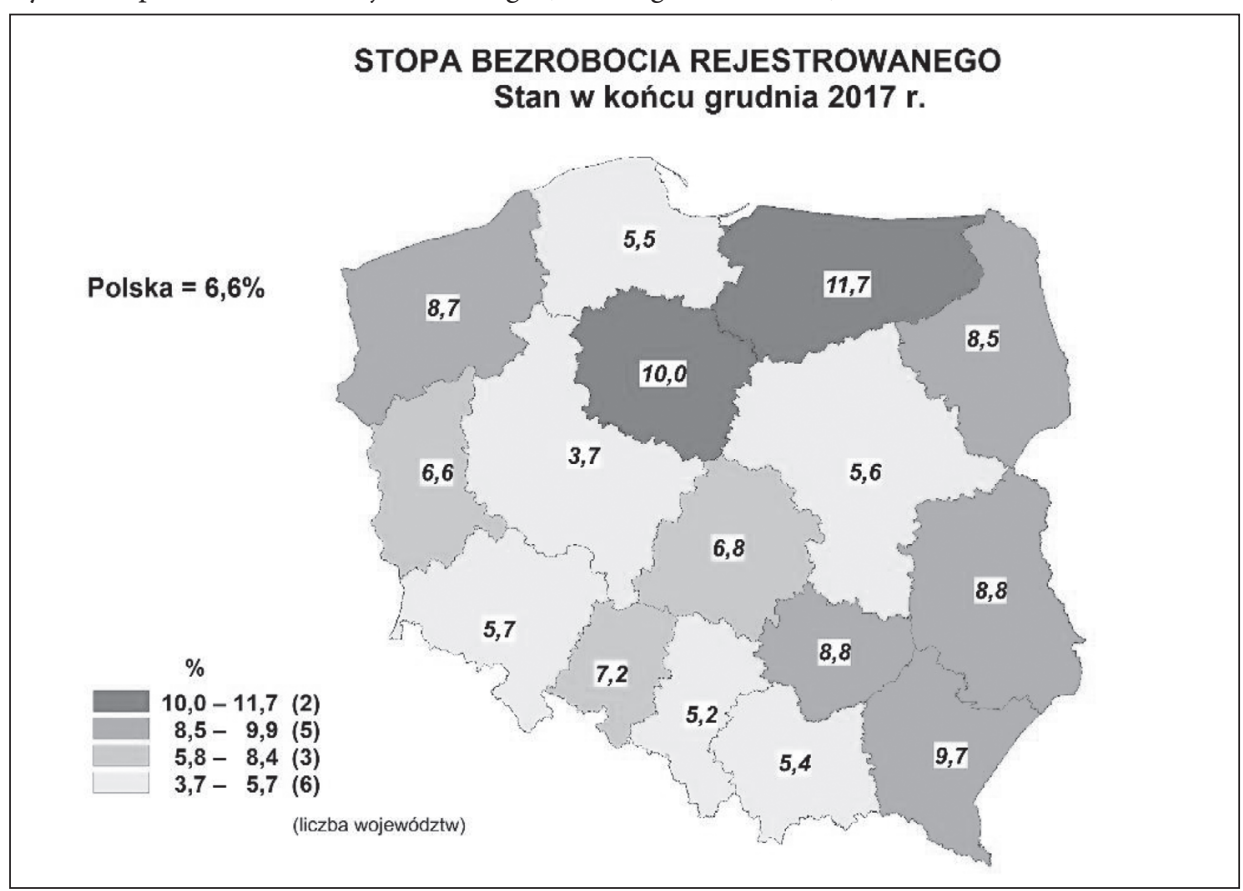

Źródło: Główny Urząd Statystyczny (2018a). 
Ryc. 5. Oferty pracy w Polsce w latach 2013-2017

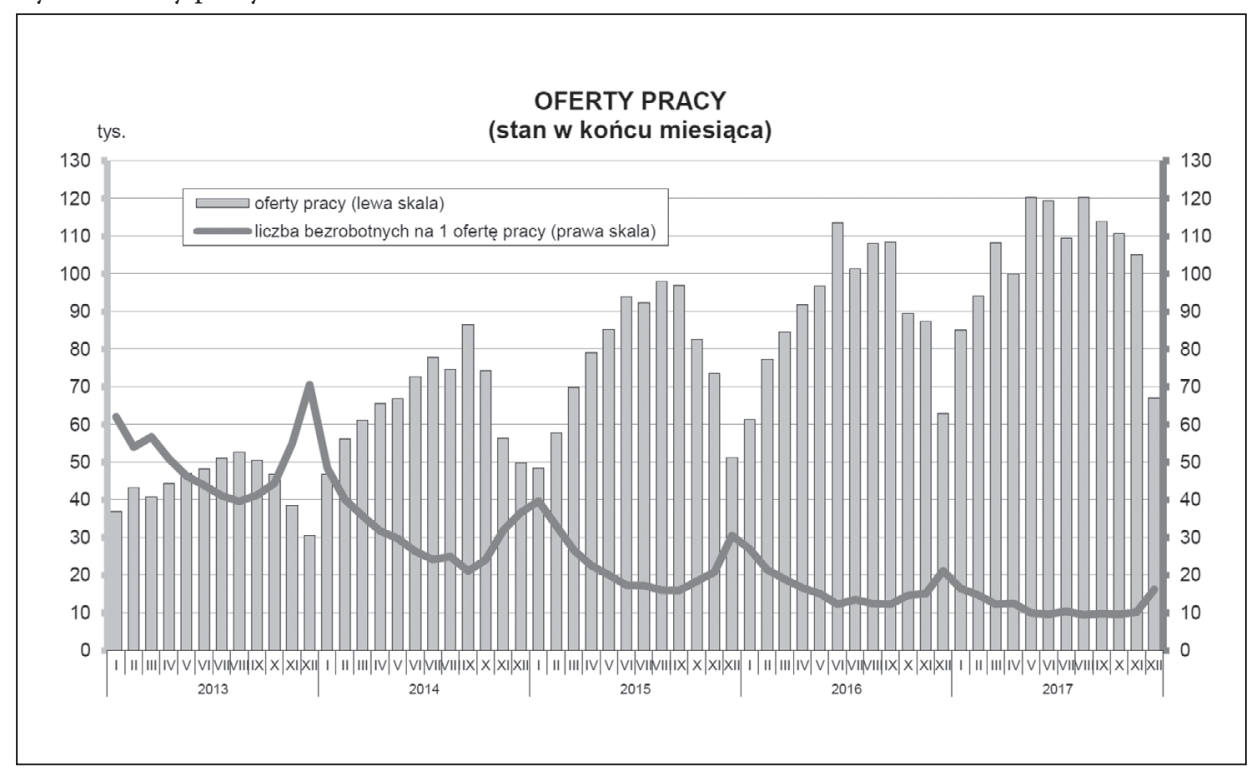

Źródło: Główny Urząd Statystyczny (2018a)

W ostatnich latach obserwuje się również zmianę w zakresie rynku pracy, tj. przejście z tzw. rynku pracodawcy do rynku pracownika. W latach 2013-2017 z roku na rok w odpowiadających sobie miesiącach obserwowano rosnącą bezwzględną liczbą ofert pracy (w miesiącach kwietniu, maju i sierpniu 2017 r. liczba ofert pracy przekraczała 120 tys.) oraz spadającą liczbę bezrobotnych przypadającą na jedną ofertę pracy (do $10 \mathrm{w}$ sierpniu 2017 roku) (ryc. 5).

Sytuacja na rynku pracy dla wkraczającej na niego młodzieży nie jest jednak aż tak bardzo korzystna. Spowodowane jest to w głównej mierze odmiennymi oczekiwaniami (często nierealnymi) młodych pracowników wobec przyszłej pracy oraz dysonansem pomiędzy owymi oczekiwaniami a rzeczywistym zapotrzebowaniem rynku i wymaganiami kompetencyjnymi pracodawców wobec młodych pracowników (Świętek, 2012).

Oferowanych miejsc pracy jest bardzo dużo, lecz w większości na stanowiskach, na których nie bierze pod uwagę młodzieży wkraczającej na rynek pracy (Świętek, 2014). Pod koniec 2017 r. największe zapotrzebowanie było bowiem na robotników przemysłowych i rzemieślników $(28,1 \%)$, operatorów i monterów maszyn i urządzeń $(17,2 \%)$. Potrzebowano też w znacznej mierze specjalistów (16,0\%) oraz pracowników usług osobistych i sprzedawców (12,2\%) (ryc. 6). Zapotrzebowanie takie rozmija się z planami zawodowymi młodych ludzi, którzy chcą zdobyć wykształcenie wyższe i oczekują pracy zgodnej ze swoim wykształceniem (Świętek, 2012).

Na sytuację młodych ludzi na rynku pracy składa się wiele zmiennych i czynników. Szeroką ich prezentację znaleźć można w raportach Bilans kapitału ludzkiego (Polska Agencja..., 2017) i Wsparcie młodych osób na mazowieckim rynku pracy (Mazowieckie Obserwatorium..., 2014). Analiza raportów wykazała, że najistotniejszymi negatywnymi czynnikami wpływającymi na sytuację młodych osób na rynku pracy, generującymi ich wkraczanie do grupy NEET, są: 
Ryc. 6. Struktura wolnych miejsc pracy wg zawodów (stan na IV kwartał 2017 r.)

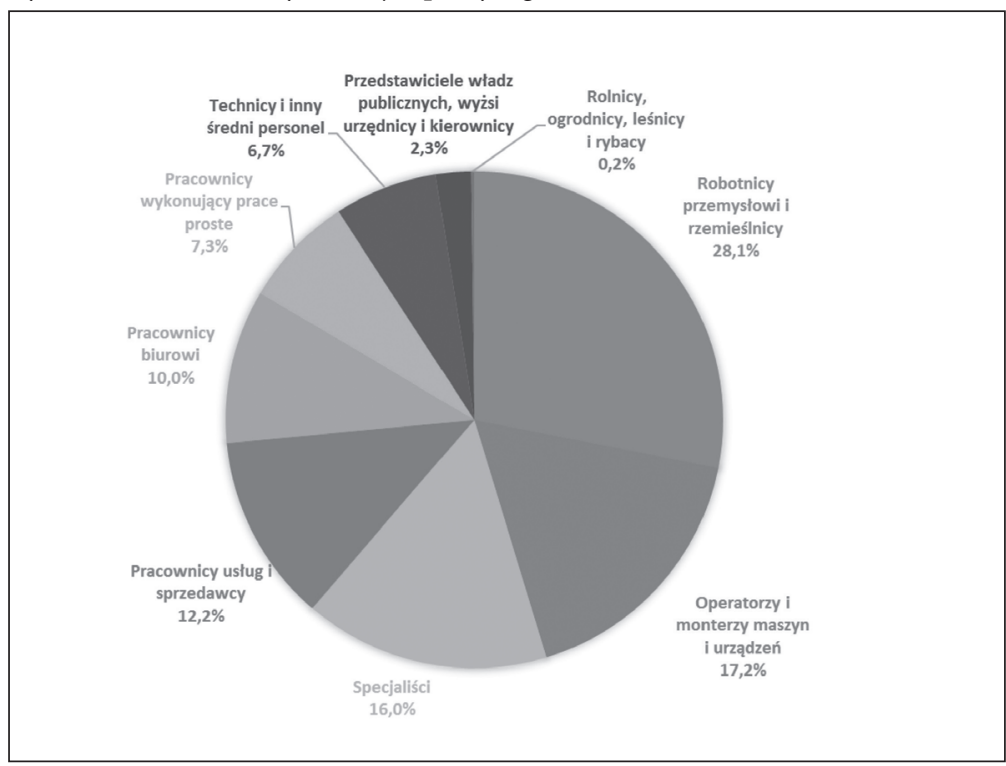

Źródło: opracowane własne na podstawie GUS (2018b)

- długotrwałe bezrobocie w regionie,

- segmentacja rynku pracy (podział na stabilny rynek etatowych pracowników i rynek pracowników tymczasowych),

- nieelastyczność rynku pracy (pracodawcy nie chcą dofinansowywać inicjacji zawodowej osób młodych, nie widzą korzyści w zatrudnianiu osób dopiero wkraczających na rynek pracy, poszukują ludzi z doświadczeniem),

- słaba (niedostosowana do potrzeb) jakość instytucji edukacyjnych i problem niedopasowania kompetencyjnego młodych do oczekiwań pracodawców,

- problemy polskich uczniów z zadaniami, w których trzeba się wykazać samodzielnością myślenia, formułowaniem własnych wniosków i szukaniem nowych rozwiązań,

- brak praktycznych umiejętności młodzieży, wymaganych przez pracodawców na rynku pracy,

- wymaganie przez pracodawców od kandydatów do pracy konkretnych kompetencji zawodowych, a także umiejętności miękkich,

- występowanie znaczącej luki między najbardziej oczekiwanymi przez pracodawców a posiadanymi przez absolwentów szkół kompetencjami (największe rozbieżności dotyczą: umiejętności określania i uzasadniania priorytetów, umiejętności organizacji pracy i zarządzania czasem oraz efektywnej komunikacji).

Liczba wskazanych uwarunkowań sprawia badaczom znaczne trudności z dokonywaniem pomiaru statystycznego i analizą sytuacji młodzieży na rynku pracy. Do wieloaspektowej oceny tego zjawiska najlepszymi wydają się być więc miary syntetyczne. Pierwszy w Polsce wskaźnik syntetyczny oceny sytuacji młodzieży na rynku pracy i czynników determinujących tę sytuację opracowano w ramach prac nad tworzeniem modelu monitorowania sytuacji młodzieży na rynku pracy w latach 2011-2012. Model wykorzystujący podejście ekspercko-statystyczne jest wynikiem prac obserwatoriów rynku pracy przy 


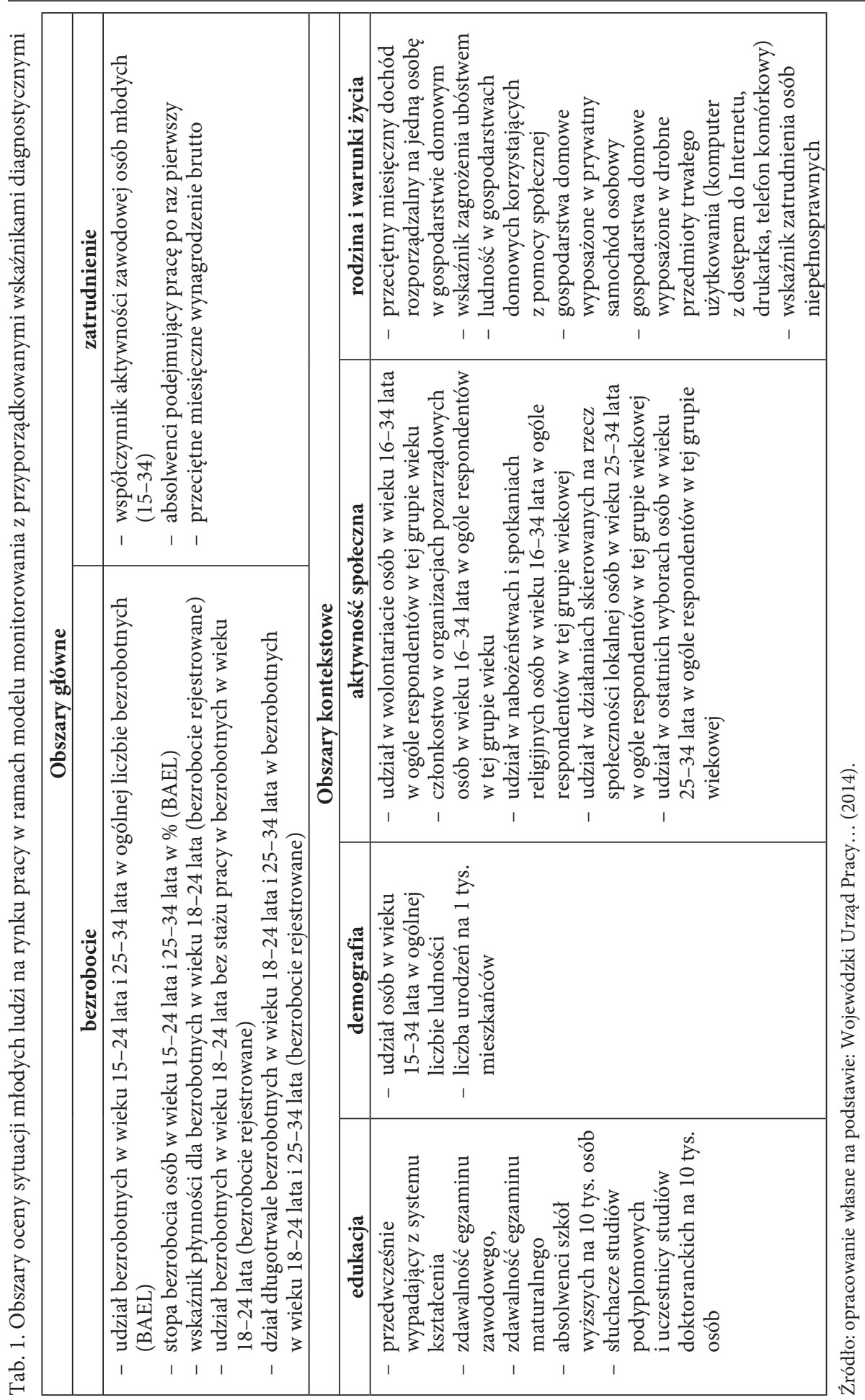


wojewódzkich urzędach pracy w Warszawie, Krakowie, Gdańsku, Poznaniu, Rzeszowie, Szczecinie i Białymstoku oraz członków European Network on Regional Labour Market Monitoring (Wojewódzki Urząd Pracy..., 2014).

W konstrukcji wskaźnika syntetycznego oceny sytuacji młodych osób na rynku pracy, spośród analizowanych 30 różnorodnych wskaźników wybrano te, które posłużą do diagnozy sytuacji młodych ludzi w wyznaczonych 6 obszarach. Do obszarów tych zaliczono: obszary główne, za jakie uznano „bezrobocie” i „zatrudnienie”, oraz obszary kontekstowe, takie jak: „edukacja”, „demografia”, „aktywność społeczna”, „rodzina i warunki życia”. Sytuacja młodych osób na rynku. Dla każdego obszaru wybrano wskaźniki diagnostyczne, które stały się składowymi miary syntetycznej. Konstruując miarę syntetyczną, poszczególnym obszarom nadano następujące rangi: „bezrobocie” 0,25 , „zatrudnienie” 0,25 , „edukacja” 0,15 , „aktywność społeczna” 0,15 , „demografia” 0,10 , „rodzina i warunki życia” 0,10. Wskaźniki składowe poszczególnych obszarów zestawiono w tabeli 1 .

Obliczony na podstawie przedstawionych założeń wskaźnik syntetyczny wykazał zróżnicowanie przestrzenne sytuacji młodzieży na rynku pracy w Polsce w roku 2011 (ryc. 7). Najlepsza sytuacja młodzieży (z najwyższym poziomem wskaźnika) występowała w województwach małopolskim, mazowieckim i pomorskim. Najsłabsza natomiast była w województwie warmińsko-mazurskim. Na mapie Polski zaznaczyła się wyraźna różnica pomiędzy wschodem a zachodem - w województwach wschodnich sytuacja młodych ludzi na rynku pracy była dużo gorsza niż w województwach zachodnich, choć należy zauważyć, że również nienajlepsza sytuacja panowała w woj. zachodniopomorskim. Widać jednak znaczące różnice wewnętrzne, na co wskazuje wpływ poszczególnych wskaźników na wartość miernika syntetycznego w konkretnych województwach. W wielu regionach

Ryc. 7. Zróżnicowanie wskaźnika syntetycznego sytuacji młodzieży na rynku pracy w Polsce w 2011 r.

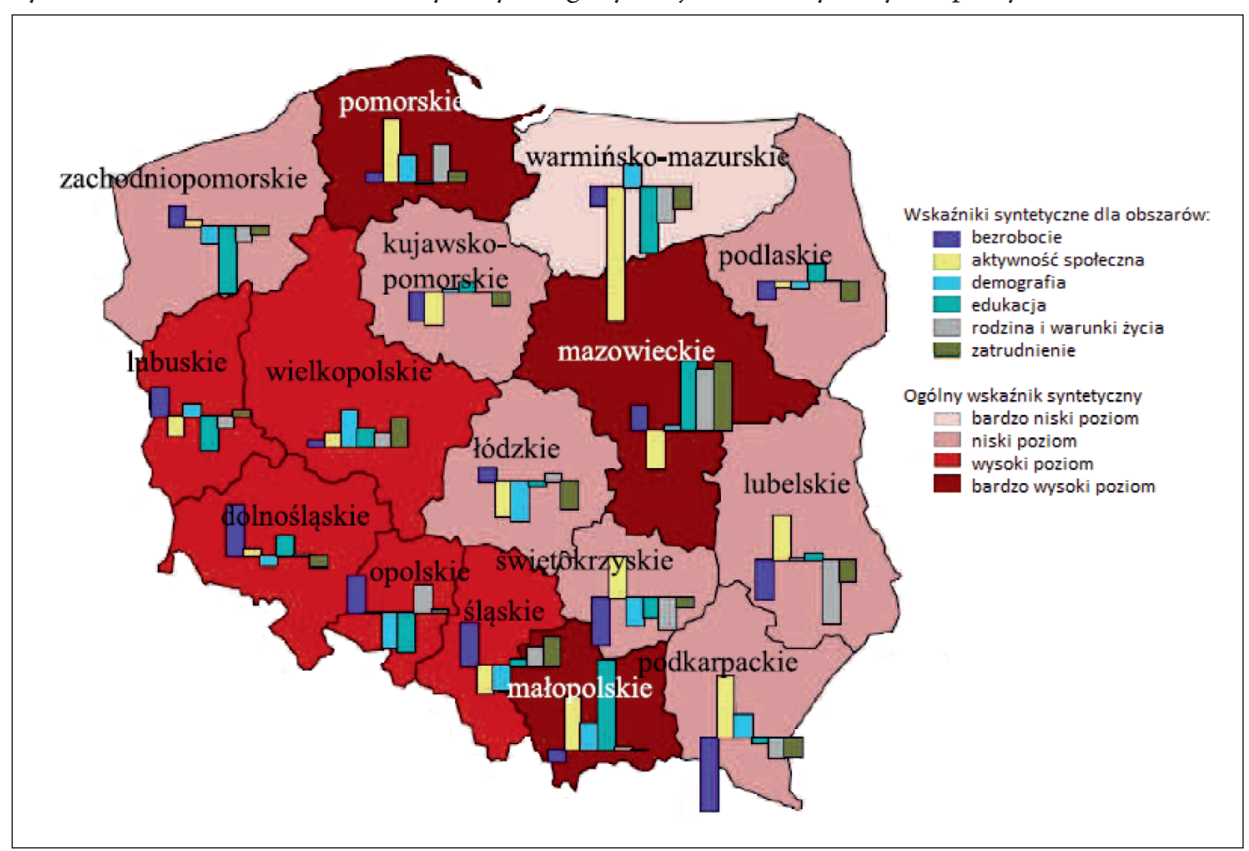

Źródło: Wojewódzki Urząd Pracy... (2014) 
(np. warmińsko-mazurskie, łódzkie, kujawsko-pomorskie) zaznacza się ich niska aktywność społeczna i problemy związane z edukacją (oprócz warmińsko-mazurskiego i łódzkiego także zachodniopomorskie, lubuskie, opolskie czy śląskie), które rekompensowane są częściowo przez inne czynniki. W województwach Polski wschodniej, takich jak lubelskie i podkarpackie, na niską wartość miernika syntetycznego wpływa korzystnie poziom edukacji i aktywności społecznej. Wskazuje to na potrzebę przyjęcia strategii działania opierającej się na szczegółowej diagnozie sytuacji w poszczególnych regionach, gdyż w tej sytuacji tylko precyzyjne określenie celów i działań w odniesieniu do poszczególnych województw może dać korzystny efekt.

Z punktu widzenia rozważań autorów najciekawsze są jednak wyniki poszczególnych województw w obszarze składowym miernika „edukacja”. Porównując dane o rozmieszczeniu NEET w Polsce wg regionów z poniższą mapą zróżnicowania poziomu wskaźnika syntetycznego (ryc. 7), uwzględniającą wskaźniki dla poszczególnych obszarów, można zauważyć pewną zależność. Otóż w województwach, w których poziom wskaźnika wyłącznie w zakresie edukacji był najniższy - występował największy odsetek NEET wśród ogółu młodzieży. Zależność tę najwyraźniej można zaobserwować w przypadku województw: warmińsko-mazurskiego, zachodniopomorskiego i lubuskiego, gdzie wyjątkowo złe poziomy wskaźników edukacyjnych przełożyły się silnie na bardzo niski poziom miernika syntetycznego w ogóle.

\section{Rozwój kompetencji przedsiębiorczych jako szansa dla młodzieży NEET}

Analiza sytuacji młodzieży wkraczającej w dorosłe życie w Polsce wskazuje na kluczowe znaczenie edukacji, w szczególności edukacji w zakresie przedsiębiorczości, w poprawie sytuacji edukacyjno-zawodowej tejże młodzieży, a przez to zwiększenie jej szans na dorosłe życie na dobrym poziomie i o dobrej jakości. Wskazywane przez badaczy zjawiska związane z NEET oraz deficyty, które zdaniem pracodawców są przyczynami trudności z odnalezieniem się młodzieży na rynku pracy okazują się być deficytami w zakresie kompetencji przedsiębiorczych. Jest to bardzo szeroki zakres, który obejmuje szereg cech i zachowań (Rachwał, 2005; Płaziak, Szymańska, 2014; Wach, 2013, 2014). Na podstawie analizy literatury przedmiotu i wyników badań wstępnych uzyskanych w projekcie RLG („Reaching the Lost Generation” - projekt został omówiony poniżej), do kompetencji przedsiębiorczych zaliczono: chęć uczenia się, umiejętności interpersonalne (w zakresie komunikacji ${ }^{1}$ i współpracy z innymi osobami), silną inicjatywność, umiejętność, rozwiązywania problemów, planowania i organizowania, podejmowania decyzji, a także gotowość podejmowania ryzyka i przyjmowania odpowiedzialności, zdolność adaptacji i elastyczność oraz myślenie biznesowe. Taki punkt widzenia na szeroko rozumianą przedsiębiorczość jako zespół kompetencji jest powszechnie przyjmowany przez wielu autorów i nawiązuje do definicji przedsiębiorczości jako kompetencji kluczowej.

Jak zauważyła D. Piróg (2014: 364), kompetencje przedsiębiorcze są „znaczącym elementem kapitału ludzkiego, są one zarówno kluczową determinantą powstawania i efektywnego prosperowania przedsiębiorstw, a także pomyślnego wejścia na rynek pracy najemnej, jak i rozwijania kariery zawodowej. Badacze reprezentujący różne dyscypliny

\footnotetext{
${ }^{1} \mathrm{Na}$ szczególną rolę kompetencji w zakresie komunikacji interpersonalnej nie tylko uczniów, ale też nauczycieli zwracał uwagę W. Osuch (2011).
} 
naukowe są zgodni, że w warunkach kryzysu gospodarczego i turbulentnego rynku pracy kompetencje te stanowią fundament efektywnego funkcjonowania jednostki w społeczeństwie na różnych płaszczyznach życia zawodowego i pozazawodowego". Koniecznym jest więc kształtowanie kompetencji przedsiębiorczych młodzieży przed jej wejściem w dorosłe życie, a najlepiej - rozwijanie ich w szkołach przy różnych okazjach i na różnych etapach edukacyjnych, nie tylko w ramach lekcji przedsiębiorczości.

Przykładami stosunkowo łatwych do wykorzystania narzędzi, które pozwalają na efektywne podniesienie poziomu kompetencji przedsiębiorczych młodzieży szkół średnich, są materiały dydaktyczne wypracowane w ramach projektu RLG, którego współtwórcami byli autorzy niniejszego artykułu.

Projekt RLG był współfinansowany ze środków UE w ramach programu Erasmus+ i realizowany w latach 2014-2017. Partnerami - twórcami projektu były cztery zespoły z następujących instytucji: EduNet Foundation for New Educational Resources (Węgry), Euro Training Centre (Niemcy), Train'd Up (Wielka Brytania) oraz Uniwersytet Pedagogiczny w Krakowie (Polska), które stworzyły międzynarodowy zespół partnerów. Ponadto w każdym kraju zespoły współpracowały z placówkami oświatowymi. W Polsce były to szkoły ponadgimnazjalne: Powiatowe Centrum Kształcenia Zawodowego i Ustawicznego w Wieliczce oraz XI Liceum Ogólnokształcące w Krakowie.

Grupą docelową projektu byli młodzi ludzie w wieku 16-24 lata pozostający poza zatrudnieniem, o niskim poziomie kwalifikacji i aktywności na rynku pracy, określani w literaturze jako właśnie NEET lub tzw. lost generation. Łączną grupę badawczą młodzieży stanowiło 96 osób z 4 wymienionych krajów.

Głównym celem projektu było rozwijanie postaw przedsiębiorczych u osób w wieku 16-24 lata, aby zwiększyć ich aktywność w zakresie zdobywania kwalifikacji i stworzyć im szanse odnalezienia się na rynku pracy. W kolejnych fazach projektu międzynarodowe zespoły podczas współpracy:

- wskazały, na podstawie kwerendy literatury, wyników dotychczasowych badań i własnych doświadczeń w zakresie edukacji z przedsiębiorczości, kompetencje przedsiębiorcze kluczowe dla rozwoju uczestników projektu,

- opracowały materiały ćwiczeniowe dla grupy docelowej w zakresie rozwijania kompetencji biznesowych i społecznych,

- dokonały wstępnej oceny kompetencji uczniów (w trakcie tzw. assessment day),

- przeprowadziły 12-tygodniowe warsztaty pilotażowe rozwoju kompetencji dla grupy docelowej z wykorzystaniem opracowanych ćwiczeń, po których oceniony został postęp w rozwijaniu kluczowych kompetencji,

- monitorowały grupę docelową przez 12 miesięcy od ukończenia szkolenia w zakresie jej aktywności na rynku pracy (uzyskanie zatrudnienia, założenie własnej firmy, podnoszenie kwalifikacji).

Najważniejszym etapem projektu były pilotażowe warsztaty rozwijające kompetencje przedsiębiorcze. Ich uczestnicy odbyli kilkadziesiąt oryginalnych, aktywizujących ćwiczeń grupowych lub indywidualnych, w trakcie których stawiani byli w realnych lub czasem abstrakcyjnych sytuacjach zmuszających do skutecznej komunikacji i pracy w grupie, poszukiwania kreatywnych rozwiązań, planowania, a następnie sumiennego wykonywania zadań często w drodze śmiałego i odpowiedzialnego podejmowania decyzji. Po zakończeniu warsztatów dokonano badania oceny poziomu ich kompetencji przedsiębiorczych, a wyniki porównano z oceną tych samych kompetencji, której uczestnicy dokonali przed 
Ryc. 8. Rozwój kompetencji przedsiębiorczych w ramach projektu RLG - wyniki oceny wstępnej i końcowej kompetencji uczniów szkół pilotażowych - XI LO w Krakowie, technikum w PCKZiU Wieliczka (wg opinii uczestników w \%).

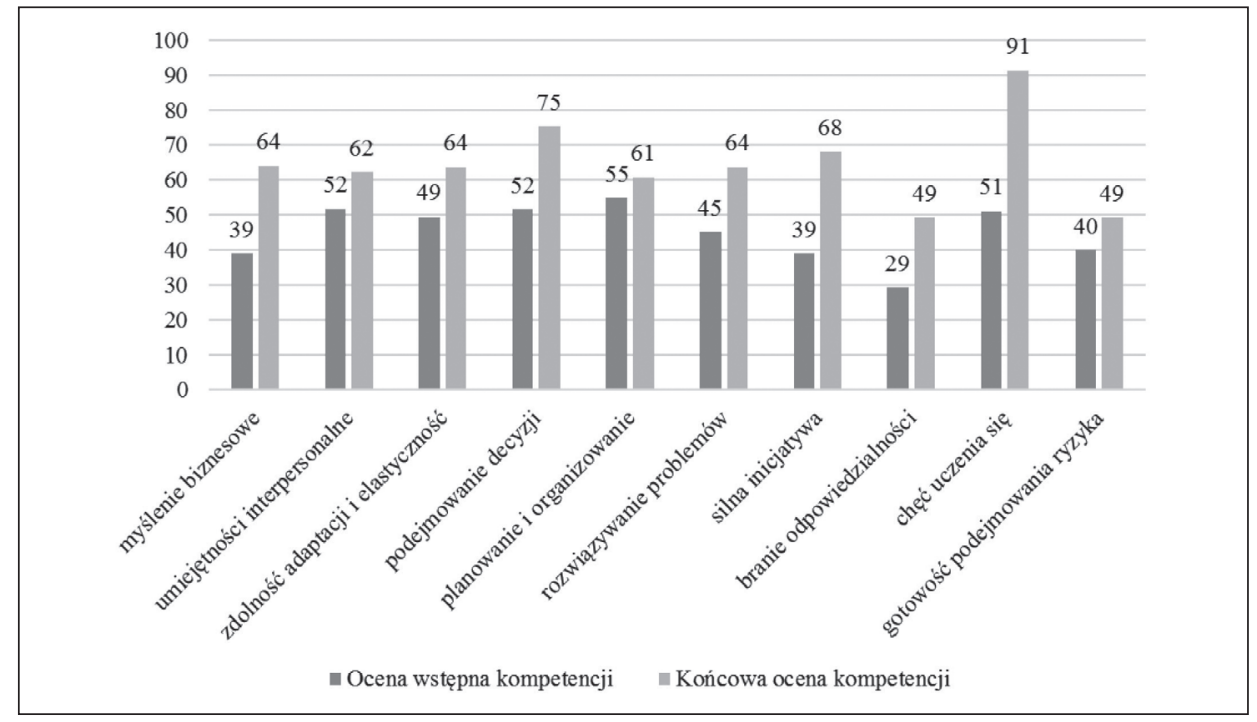

Źródło: opracowanie własne na podstawie badań własnych

ich rozpoczęciem. Wyniki (będące subiektywną oceną uczestników warsztatów) okazały się bardzo pozytywne. W przypadku wszystkich 10 kompetencji rozwijanych w projekcie uczestnicy uznali, że ich poziom się podniósł. Największy postęp, zdaniem uczestników, poczynili oni w zakresie chęci uczenia się, a zatem podnieśli swą motywację do dalszego rozwoju. Zdecydowanie podnieśli również swe kompetencje w zakresie myślenia biznesowego oraz umiejętności podejmowania decyzji.

Skuteczność narzędzi projektu RLG w zakresie podnoszenia kompetencji przedsiębiorczych wskazuje, że powinny być one wykorzystywane w toku kształcenia $\mathrm{z}$ zakresu przedsiębiorczości w szkołach średnich, tym bardziej, że są materiałami ogólnodostępnymi i darmowymi dla nauczycieli, jak każdy efekt dydaktyczny prac projektowych finansowanych z funduszy unijnych.

Podstawową możliwą formą wykorzystania narzędzi RLG w szkole jest wykorzystywanie wybranych ćwiczeń warsztatowych w trakcie lekcji podstaw przedsiębiorczości. W tabeli 2 zestawiono treści kształcenia podstaw przedsiębiorczości zawarte w podstawie programowej dla szkoły ponadgimnazjalnej (Rozporzadzenie z 27 sierpnia 2012 r. ..., 2012), które można zrealizować w ten właśnie sposób. Analiza zapisów podstawy programowej wskazuje, że materiały dydaktyczne do ćwiczeń mogą być wykorzystane w trakcie realizacji całego działu I - Człowiek przedsiębiorczy, działu V - Przedsiębiorstwo oraz niektórych treści kształcenia w ramach działu VI - Praca. Jak wskazuje dotychczasowa dyskusja nad kształtem reformy oświaty w zakresie edukacji ekonomicznej dla szkół średnich (Rachwał, 2017), podobne cele i treści kształcenia powinny być zapisane w nowej podstawie programowej z podstaw przedsiębiorczości, która do szkół średnich ma wejść od roku szkolnego 2019/2020. Możliwe będzie zatem wykorzystanie wypracowanych materiałów także w nowych warunkach systemy szkolnego. 
Tab. 2. Treści kształcenia podstaw przedsiębiorczości w szkole ponadgimnazjalnej możliwe do zrealizowania z wykorzystaniem narzędzi projektu RLG

\begin{tabular}{|l|}
\hline \multicolumn{1}{|c|}{ I. Człowiek przedsiębiorczy } \\
\hline Uczeń: \\
Przedstawia cechy, którymi charakteryzuje się osoba przedsiębiorcza \\
Rozpoznaje zachowania asertywne, uległe i agresywne, odnosi je do cech osoby \\
przedsiębiorczej \\
Rozpoznaje mocne i słabe strony własnej osobowości, odnosi je do cech osoby przedsiębiorczej \\
Charakteryzuje swoje role społeczne i typowe dla nich zachowania \\
Zna korzyści wynikające z planowania własnych działań i inwestowania w siebie \\
Analizuje przebieg kariery zawodowej osoby, która zgodnie z zasadami etyki odniosła sukces \\
w życiu zawodowym \\
Podejmuje racjonalne decyzje, opierając się na posiadanych informacjach, i ocenia skutki \\
własnych działań \\
Stosuje różne formy komunikacji werbalnej i niewerbalnej w celu autoprezentacji \\
oraz prezentacji własnego stanowiska \\
Przedstawia drogę, którą dochodzi się własnych praw w roli członka zespołu, pracownika, \\
konsumenta
\end{tabular}

Źródło: opracowanie własne (zapisy i numeracja wg Rozporządzenie z dnia 27 sierpnia 2012 r. ..., 2012).

Prócz wplatania ćwiczeń projektowych w tok lekcji podstaw przedsiębiorczości, realizując powyższe treści kształcenia, materiały przygotowane w trakcie projektu można zastosować również na wybranych lekcjach geografii czy wiedzy o społeczeństwie, które ze względu na swój zakres treści kształcenia i cele dydaktyczne w znacznym stopniu sprzyjają kształtowaniu postaw przedsiębiorczych uczniów (zob. Borowiec, Rachwał 2011). Trening kompetencji przedsiębiorczych jest również dobrym pomysłem na rozwijanie uczniów w trakcie lekcji wychowawczych. Zdaniem autorów korzystne dla uczniów byłoby uwzględnienie go w programie wychowawczo-profilaktycznym szkoły. Rozwój kompetencji 
przedsiębiorczych drogą aktywizujących ćwiczeń można wreszcie wykorzystać w ramach realizacji powszechnie stosowanej w szkołach metody projektu - w tym przypadku - wieloprzedmiotowego, w ramach dni otwartych szkoły lub jej uczestnictwa w obchodach Światowego Tygodnia Przedsiębiorczości, który corocznie odbywa się w listopadzie.

\section{Podsumowanie}

Przedstawione rozważania wskazują, że choć sytuacja na rynku pracy w Polsce, także dla ludzi młodych, systematycznie się poprawia w wyniku splotu szeregu czynników społeczno-gospodarczych, to nadal widoczne są znaczne różnice regionalne, powodujące, że w niektórych regionach bezrobocie w tej grupie osób jest dosyć wysokie. Dotyczy to szczególnie Polski północno-wschodniej i północno-zachodniej. Dobra sytuacja w Polsce na tle Europy jest także w zakresie udziału młodzieży wypadającej przedwcześnie z systemu kształcenia. Szczegółowa analiza zjawiska na poziomie województw wskazuje jednak na szereg problemów młodzieży na rynku pracy. Po pierwsze, duży dystans dzieli liderów - województwa: mazowieckie, a także pomorskie i małopolskie oraz w pewnym stopniu wielkopolskie i śląskie - od reszty kraju. W wielu województwach zaznacza się niska aktywność społeczna i problemy związane z edukacją, szczególnie w regionach pozametropolitalnych (tj. województw, których stolice nie są silnymi metropoliami o funkcjach ponadkrajowych). Choć sytuacja w województwach południowo-zachodniej Polski jest lepsza niż w województwach Polski wschodniej, to w wielu regionach zachodnich, takich jak województwo lubuskie, zachodniopomorskie, opolskie, widać problemy demograficzne oraz w obszarze edukacji. Edukacja ma z kolei duży wpływ na wysoką pozycję w zakresie sytuacji młodych na rynku pracy województw mazowieckiego i małopolskiego. Można więc przyjąć w świetle przeprowadzonych rozważań, że ten czynnik ma kluczowe znaczenie i jest zarazem w sferze możliwości stosunkowo łatwej poprawy, gdyż wymaga nie tyle ogromnych nakładów w ramach interwencjonizmu państwowego, ile zmiany podejścia do kształcenia na poziomie szkół przy wsparciu organów prowadzących, czyli głównie samorządów. Zmiana ta powinna mieć na celu lepsze kształtowanie szeroko rozumianych postaw przedsiębiorczych młodzieży. Przyjęcie takiego podejścia ukierunkowanego na przedsiębiorczość może przynieść poprawę we wszystkich obszarach problemowych, tj. wpłynąć na zmniejszenie bezrobocia na terenach, gdzie jest ono jeszcze ciągle zbyt wysokie, i zwiększenie wskaźników aktywności zawodowej. Może też zwiększyć aktywność społeczną młodzieży i przeciwdziałać jej zniechęceniu do podejmowania działań o charakterze społecznym i gospodarczym, wpłynąć korzystniej na wskaźniki demograficzne m.in. przez większą skłonność do zakładania rodzin, gdyż obawy przed wzięciem odpowiedzialności za te sprawy są tu istotnym czynnikiem hamującym, oraz w konsekwencji poprawić warunki życia. Postawy przedsiębiorcze młodzieży, nie tylko z grupy NEET, można i należy rozwijać w ramach lekcji postaw przedsiębiorczości, a także na lekcjach z innych przedmiotów, lekcjach wychowawczych i w formie zajęć dodatkowych. Aktywność szkoły w tym zakresie może przynieść bardzo pozytywne skutki, dlatego warto wypróbować materiały dydaktyczne powstałe w ramach projektów edukacyjnych, takich jak projekt edukacyjny RLG, w ramach którego powstał kompleksowy program diagnozy i rozwoju kompetencji przedsiębiorczych².

\footnotetext{
${ }^{2}$ Rezultaty realizacji programu są dostępny tutaj: https://rlg.edunet.hu/project/results
} 
Literatura

References

Balcerowicz-Szkutnik, M., Wąsowicz, J. (2017). Pokolenie NEETs na rynku pracy - aktualne problemy. Studia Ekonomiczne. Zeszyty Naukowe Uniwersytetu Ekonomicznego w Katowicach, 312, 7-17.

Borowiec, M., Rachwał, T. (2011). Kształtowanie postaw przedsiębiorczych na lekcjach geografii wyzwaniem edukacyjnym w procesach globalizacji, Przedsiębiorczość - Edukacja, 7, 321-332.

Główny Urząd Statystyczny. (2018a). Informacja o sytuacji społeczno-gospodarczej kraju w 2017 r. Warszawa: GUS.

Główny Urząd Statystyczny. (2018b). Popyt na pracęw 2017 r. Warszawa: GUS.

Kompetencje kluczowe w uczeniu się przez całe życie. Europejskie Ramy Odniesienia (2007). Urząd Oficjalnych Publikacji Wspólnot Europejskich. Luxembourg.

Krause, E. (2016). Zjawisko NEET, czyli o młodzieży trzy razy nic. Problemy Profesjologii, 2, 67-81.

Mazowieckie Obserwatorium Rynku Pracy, Wojewódzki Urząd Pracy w Warszawie. (2014). Wsparcie młodych osób na mazowieckim rynku pracy. Warszawa.

Osuch, W. (2011). Kompetencje w zakresie komunikacji interpersonalnej w dobie postępujących procesów globalizacji. Przedsiębiorczość - Edukacja, 7, 333-346.

Piróg, D. (2014). Kompetencje z zakresu przedsiębiorczości: rozważania teoretyczne i ich ilustracje w obszarze szkolnictwa wyższego. Przedsiębiorczość - Edukacja, 11, 364-376.

Płaziak, M., Szymańska, A.I. (2014). Otwartość na innowacje jako przejaw przedsiębiorczości ludzi młodych na przykładzie studentów uczelni krakowskich, Horyzonty Wychowania, 13(26), 267-286.

Polska Agencja Rozwoju Przedsiębiorczości. (2017). Bilans kapitału ludzkiego. Warszawa.

Rachwał, T. (2005). Kształtowanie postaw u uczniów na lekcjach przedsiębiorczości. Przedsiębiorczość Edukacja, 1, 137-144.

Rachwał, T. (2017). Entrepreneurship in School in the Conditions of the Education System Reform in Poland - a Voice in the Discussion on the Directions of Change. Przedsiębiorczość - Edukacja, 13, 330-339.

Rozporzadzenie Ministra Edukacji Narodowej z dnia 27 sierpnia 2012 r. w sprawie podstawy programowej wychowania przedszkolnego oraz kształcenia ogólnego w poszczególnych typach szkót (Dz.U. 2012 poz. 977).

Rybicka, K. (2014). Sytuacja młodzieży na polskim rynku pracy, Zeszyty Naukowe Uniwersytetu Szczecińskiego. Studia i Prace Wydziału Nauk Ekonomicznych i Zarzadzania, 37(2), 105-116.

Saczyńska-Sokół, S., Łojko, M. (2016). Sytuacja młodzieży NEET na rynku pracy. Zeszyty Naukowe UniwersytetuPrzyrodniczo-Humanistycznego w Siedlcach. AdministracjaiZarządzanie, 108, 97-106.

Szcześniak, M., G., (2011). Pokolenie „ani-ani”: o młodzieży, która się nie uczy, nie pracuje i nie dba o samokształcenie, Psychologia Społeczna, 3(18), 241-251.

Świętek, A. (2012). Oczekiwania a realia wejścia ludzi młodych na rynek pracy jako wyzwanie dla edukacji z przedsiębiorczości, Przedsiębiorczość - Edukacja, 8, 137- 154.

Świętek, A. (2014) Czy ekonomia w praktyce będzie przydatna w praktyce? Przedsiębiorczość - Edukacja, $10,378-391$.

Wach, K. (2013). Edukacja na rzecz przedsiębiorczości wobec współczesnych wyzwań cywilizacyjno-gospodarczych. Przedsiębiorczość - Edukacja, 9, 246-257.

Wach, K. (2014). Edukacja dla przedsiębiorczości: pomiędzy przedsiębiorczą pedagogiką a edukacją ekonomiczną i biznesową. Horyzonty Wychowania, 13(28), 11-31.

Wojewódzki Urząd Pracy w Białymstoku. (2014). Model monitorowania sytuacji osób młodych na rynku pracy. Białystok.

Agnieszka Świętek, dr, Uniwersytet Pedagogiczny im. Komisji Edukacji Narodowej w Krakowie, Instytut Geografii, Zakład Dydaktyki Geografii. Doktor nauk o Ziemi w zakresie geografii, absolwentka studiów z zakresu geografii Uniwersytetu Pedagogicznego w Krakowie w specjalności 
przedsiębiorczość i gospodarka przestrzenna. Adiunkt w Instytucie Geografii Uniwersytetu Pedagogicznego w Krakowie. Jej zainteresowania badawcze skupiają się wokół problematyki edukacji z zakresu geografii i przedsiębiorczości, a w szczególności procesu zakładania własnej działalności gospodarczej, wchodzenia młodych ludzi na rynek pracy oraz poziomu życia Romów w Polsce.

Agnieszka Świętek, PhD in Geography, graduated from the Pedagogical University in Cracow, MA degree in geography, specialisation in entrepreneurship and spatial planning. Assistant professor at the Pedagogical University of Cracow, Institute of Geography. Her research interests focus on two different research themes: the education in the field of geography and entrepreneurship, in particular the process of starting up own business, young people entering into the labour market and the quality of life of the Roma in Poland.

\section{Adres/Address:}

Uniwersytet Pedagogiczny im. Komisji Edukacji Narodowej w Krakowie

Instytut Geografii

Zakład Dydaktyki Geografii

ul. Podchorążych 2

30-084 Kraków, Polska

e-mail: Agnieszka.Swietek@up.krakow.pl

Tomasz Rachwal, dr, Uniwersytet Pedagogiczny im. Komisji Edukacji Narodowej w Krakowie, Instytut Geografii, Zakład Przedsiębiorczości i Gospodarki Przestrzennej. Dyrektor Instytutu, kierownik Zakładu. Pełni m.in. funkcje: pełnomocnika rektora UP ds. przedsiębiorczości, wiceprzewodniczącego Komisji Geografii Przemysłu Polskiego Towarzystwa Geograficznego, zastępcy redaktora naczelnego czasopism: „Przedsiębiorczość - Edukacja”, „Prace Komisji Geografii Przemysłu Polskiego Towarzystwa Geograficznego” oraz członka redakcji „Entrepreneurial Business and Economics Review”, „Geographia Polonica” oraz „Annales Universitatis Paedagogicae Cracoviensis. Studia Geographica". Jest autorem lub współautorem podręczników szkolnych i akademickich z zakresu geografii ekonomicznej i przedsiębiorczości. Jego zainteresowania badawcze skupiają się przede wszystkim na problematyce przemian struktur przestrzennych przemysłu, funkcjonowania różnych branż działalności gospodarczej, restrukturyzacji przedsiębiorstw oraz roli przedsiębiorczości w rozwoju układów przestrzennych, a także edukacji w zakresie przedsiębiorczości.

Tomasz Rachwal, PhD, Pedagogical University of Cracow, Institute of Geography, Department of Entrepreneurship and Spatial Management. Director of Institute, Head of the Department, Rector's Proxy for Entrepreneurship, a deputy chair of the Industrial Geography Commission of the Polish Geographical Society, A Deputy Editor in Chief of the following journals: "Entrepreneurship - Education", "Studies of the Industrial Geography Commission of the Polish Geographical Society", and a member of the editorial board of "Entrepreneurial Business and Economics Review", "Geographia Polonica”, “Annales Universitatis Paedagogicae Cracoviensis. Studia Geographica”. The author or co-author of school and academic textbooks on economic geography and entrepreneurship. His research interests focus primarily on the issue of change of spatial structures of industry, the functioning of various branches of industrial activity, corporate restructuring and the role of entrepreneurship in the development of spatial systems, as well as entrepreneurship education.

\section{Adres/Address:}

Uniwersytet Pedagogiczny im. Komisji Edukacji Narodowej w Krakowie

Instytut Geografii

Zakład Przedsiębiorczości i Gospodarki Przestrzennej

ul. Podchorążych 2

30-084 Kraków, Polska

e-mail: Tomasz.Rachwal@up.krakow.pl 
Sławomir Kurek, dr hab., prof. UP, Uniwersytet Pedagogiczny im. Komisji Edukacji Narodowej w Krakowie, Instytut Geografii, Zakład Geografii Społeczno-Ekonomicznej. Geograf społeczno-ekonomiczny. Członek Komitetu Nauk Demograficznych PAN. Pełni m.in. funkcję prodziekana Wydziału Geograficzno-Biologicznego, kierownika Zakładu Geografii Społeczno-Ekonomicznej, kierownika studiów doktoranckich z geografii oraz redaktora naczelnego czasopisma „Annales Universitatis Paedagogicae Cracoviensis. Studia Geographica”. Jego zainteresowania badawcze skupiają się przede wszystkim na problematyce przemian struktur społeczno-demograficznych Polski i Europy, procesów suburbanizacji w obszarach metropolitalnych oraz edukacji w zakresie przedsiębiorczości.

Sławomir Kurek, $\mathrm{PhD}$, associate professor at the Pedagogical University of Cracow, Institute of Geography, Department of Socio-Economic Geography. A socio-economic geographer. Member of the Committee on Demographic Studies of the Polish Academy of Sciences. He is, among other activities, the Vice-Dean of Geography and Biology Faculty, Head of Department of Social and Economic Geography, Head of Doctoral Studies in geography at the Pedagogical University, and Editor in Chief of "Annales Universitatis Paedagogicae Cracoviensis. Studia Geographica". Research interests focus primarily on the issue of changes of the socio-demographic structures in Poland and Europe, suburbanisation processes in metropolitan areas, as well as entrepreneurship education.

\title{
Adres/Address:
}

Uniwersytet Pedagogiczny im. Komisji Edukacji Narodowej w Krakowie Instytut Geografii

Zakład Geografii Społeczno-Ekonomicznej

ul. Podchorążych 2

30-084 Kraków, Polska

e-mail: Slawomir.Kurek@up.krakow.pl

Wioletta Kilar, dr, Uniwersytet Pedagogiczny im. Komisji Edukacji Narodowej w Krakowie, Instytut Geografii, Zakład Przedsiębiorczości i Gospodarki Przestrzennej. Geograf ekonomiczny, adiunkt w Zakładzie Przedsiębiorczości i Gospodarki Przestrzennej Instytutu Geografii Uniwersytetu Pedagogicznego w Krakowie, wicedyrektor ds. dydaktycznych i studenckich Instytutu Geografii. Jej zainteresowania badawcze ukierunkowane są przede wszystkim na procesy kształtowania się i funkcjonowania ponadnarodowych korporacji, globalizacji, przemian struktur przestrzennych przemysłu oraz problematykę nauczania przedsiębiorczości i geografii w szkole.

Wioletta Kilar, PhD, Pedagogical University of Cracow, Institute of Geography, Department of Entrepreneurship and Spatial Management. An economic geographer. She is currently employed as an assistant professor in the Department of Entrepreneurship and Spatial Management in the Institute of Geography at the Pedagogical University of Cracow. She is deputy director of Institute of Geography for Studies and Student Affairs. Her research interests focus primarily on the processes of formation and operation of multinational corporations; globalisation; transformation of spatial structures of industry; and issues of teaching entrepreneurship and geography in schools.

\author{
Adres/Address: \\ Uniwersytet Pedagogiczny im. Komisji Edukacji Narodowej w Krakowie \\ Instytut Geografii \\ Zakład Przedsiębiorczości i Gospodarki Przestrzennej \\ ul. Podchorążych 2 \\ 30-084 Kraków, Polska \\ e-mail: Wioletta.Kilar@up.krakow.pl
}


Wiktor Osuch, dr hab., prof. UP, Uniwersytet Pedagogiczny im. Komisji Edukacji Narodowej w Krakowie, Instytut Geografii, Zakład Dydaktyki Geografii. Urodzony w Krakowie, absolwent kierunku geografia na Uniwersytecie Pedagogicznym w Krakowie, doktor habilitowany nauk społecznych. Prodziekan Wydziału Geograficzno-Biologicznego. Jest pracownikiem naukowo-dydaktycznym w Zakładzie Dydaktyki Geografii, Instytutu Geografii Uniwersytetu Pedagogicznego w Krakowie. Prowadzi zajęcia dydaktyczne m.in. z dydaktyki geografii w gimnazjum i szkole ponadgimnazjalnej, komunikacji interpersonalnej. Jego zainteresowania naukowe w obrębie dydaktyki geografii i przedsiębiorczości obejmują: kształcenie nauczycieli, praktyki nauczania w szkole, profesjonalne kompetencje nauczycieli geografii, kompetencje kluczowe, metody kształcenia, programy nauczania i podręczniki.

Wiktor Osuch, $\mathrm{PhD}$, associate professor at the Pedagogical University of Cracow, Institute of Geography, Department of Didactics of Geography. He was born in Cracow and has graduated from the Faculty of Geography at the Pedagogical University of Cracow, associate professor in the field of social sciences, the Deputy Dean of Faculty of Geography and Biology. He is a university lecturer employed in the Didactics of Geography Department, Institute of Geography at the Pedagogical University of Cracow. Vice-Dean of Geography and Biology Faculty. Teaching duties (courses taught): didactics of geography in lower and upper secondary schools, interpersonal communication, student's teaching practice, concepts of the education internships, didactic geography seminar. Research interest in the field of didactic geography and entrepreneurship education: teacher's education, teaching practice, geography teacher's professional competences, key competences, teaching methods, geography curriculum and school-books.

\section{Adres/Address:}

Uniwersytet Pedagogiczny im. Komisji Edukacji Narodowej w Krakowie

Instytut Geografii

Zakład Dydaktyki Geografii

ul. Podchorążych 2

30-084 Kraków, Polska

e-mail: Wiktor.Osuch@up.krakow.pl

Publikacja powstała w ramach projektu „Reaching the Lost Generation” (RLG), realizowanego przy wsparciu finansowym Komisji Europejskiej w ramach Programu „Erasmus+”.

Publikacja odzwierciedla jedynie stanowisko jej autorów i Komisja Europejska oraz Narodowa Agencja Programu Erasmus+ nie ponoszą odpowiedzialności za umieszczoną w niej zawartość merytoryczną.
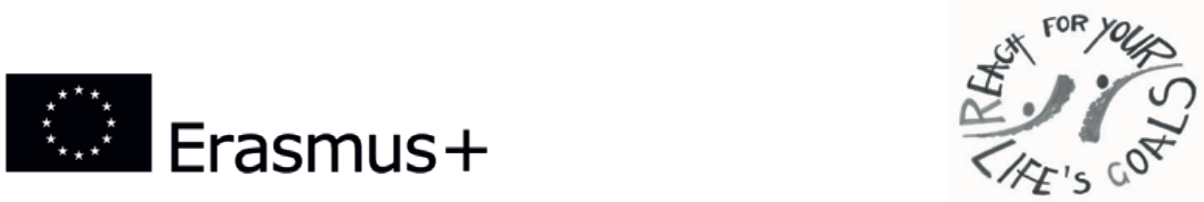